\title{
Religião, política e liberdade: Contribuições de Baruch Espinoza
}

\author{
Igor Castellano da Silva* \\ Gabriela Schneider**
}

\section{Resumo}

Há décadas existem discussões sobre a separação entre religião e política e religião e esfera pública que focam sobretudo nos limites desse mito moderno e nas possibilidades de coexistência dessas esferas no mundo contemporâneo. No entanto, pouco se explora sobre origens filosóficas de visões intermediárias, que concebem a inevitável influência do universo sagrado no mundo profano, mas questiona os limites plausíveis que a religião deve construir para garantir paz, direitos fundamentais e liberdades mais amplas. Este ensaio rastreia tais origens filosóficas no pensamento de Baruch Espinoza e o contrasta com a utopia liberal restrita de John Locke, amplamente propagada, mas irrealizável em tempos de separação apenas formal entre religião e política, objetivando resgatar discussões relevantes acerca do debate religião-política para nossos dilemas contemporâneos.

Palavras-chave: Baruch Espinoza. Direitos fundamentais. Liberdade. Religião. Política.

* Professor Adjunto do Departamento de Economia e Relações Internacionais da Universidade Federal de Santa Maria (UFSM). Professor do corpo permanente do Programa de Pós-Graduação em Relações Internacionais (PPGRI) e do Pós-Graduação em Economia e Desenvolvimento (PPGE\&D), ambos da UFSM. Doutor em Estudos Estratégicos Internacionais (2015) pela Universidade Federal do Rio Grande do Sul (UFRGS), com período sanduíche na University of Johannesburg, África do Sul (2013). Mestre em Ciência Política (2011) e bacharel em Relações Internacionais (2008) pela UFRGS. E-mail: igor. castellano@gmail.com. Lattes: http://lattes.cnpq.br/7301233930780970.

** Doutoranda em Comunicação pela Universidade Federal de Santa Maria (UFSM). Mestra em Direito (2014) pela Universidade do Vale do Rio dos Sinos (UNISINOS). Especialista em Direito Penal e Processual Penal (2011) e bacharela em Direito (2009), pela Universidade do Vale do Rio dos Sinos (UNISINOS). Advogada. Contato: schd.gabriela@gmail.com. Lattes: http://lattes.cnpq.br/0151549087457114. 


\title{
Religion, politics and freedom: Contributions of Baruch Spinoza
}

\begin{abstract}
For decades, discussions about the separation between religion and politics and religion and the public sphere have been that focus mainly on the limits of this modern myth and the possibilities of coexistence of these spheres in the contemporary world. However, philosophical origins of intermediate views, like conceive the inevitable influence of the sacred universe in the profane world, but question the plausible limits that religion must build to guarantee peace, fundamental rights and broader freedoms are little explored. This study traces such philosophical origins in Baruch Spinoza's thinking and contrasts it with John Locke's restricted liberal utopia - wich is widely propagated but unrealizable in times of only formal separation between religion and politics. The objective is to rescue relevant discussions about the religious-political debate for our contemporary dilemmas.
\end{abstract}

Keywords: Fundamental rights. Religion. Politics.

\section{Religión, política y libertad: contribuciones de Baruch Espinoza}

\section{Resumen}

Desde hace décadas se habla de la separación entre religión y política así como religión y esfera pública que se centran principalmente en los límites de este mito moderno y las posibilidades de convivencia de estas esferas en el mundo contemporáneo. Sin embargo, poco se explora sobre los orígenes filosóficos de visiones intermedias, que conciben la influencia inevitable del universo sagrado en el mundo profano, pero cuestionan los límites plausibles que la religión debe construir para garantizar la paz, los derechos fundamentales y libertades más amplias. Este ensayo rastrea estos orígenes filosóficos en el pensamiento de Baruch Espinoza y lo contrasta con la utopía liberal restringida de John Locke, ampliamente propagada pero irrealizable en tiempos de separación solo formal entre religión y política, con el objetivo de rescatar discusiones relevantes sobre el debate político-religioso para nuestros dilemas contemporáneos.

Palabras claves: Baruch Espinoza. Derechos fundamentales. Religión. Política.

\section{Introdução}

A influência da religião, desde a religiosidade individual até sistemas religiosos consolidados, na política doméstica e internacional tem sido tema de grande debate público e acadêmico nas últimas décadas (FOX; SANDLER, 2004; SNYDER, 2011; SHAH; PHILPOTT, 2011; RENGGER, 2013; DARK, 2000; HATZOPOULOS; PETITO, 2004; WARNER; WALKER, 2011). Discussões sobre a separação entre religião e política e religião e esfera pública focam sobretudo nos limites desse mito moderno e nas 
possibilidades de coexistência dessas esferas no mundo contemporâneo (ASAD, 2003; TAYLOR, 2007; BURITY, 2001, 2008; ORO, 2011; DAVIE, 2019). Por um lado, a perspectiva política liberal foca nos limites atribuídos a cada espaço e a efetivação da garantia legal de suas respectivas liberdades, remontando à filosofia política liberal Lockeana. Por outro lado, diferentes visões teológicas e filosóficas pré e pós-modernas apregoam a necessidade e/ ou o inescapável destino de ressignificar a política com valores sagrados, por vezes justificando regimes teocráticos, confessionais e/ou segregacionistas (HUNTINGTON, 1993, 2004; JAWAD, 1997; FOX, 2013; MILLER, 2014; MACHADO, 2006). Entretanto, pouco se vislumbra sobre origens filosóficas de visões intermediárias, que concebem a inevitável influência do universo sagrado no mundo profano, mas questiona os limites plausíveis que a religião deve construir para garantir paz, direitos fundamentais e liberdades mais amplas. Este ensaio rastreia tais origens filosóficas no pensamento de Baruch Espinoza e o contrasta com a utopia liberal restrita de John Locke, amplamente propagada, mas irrealizável em tempos de separação apenas formal (quando muito) entre religião e política.

O século XVII presenciou o ápice das guerras religiosas na Europa, principalmente pelo marco da Guerra dos 30 Anos (1618-1648) e da Guerra Civil Inglesa (1642-1649). Viveu-se os reflexos políticos do extremismo religioso, plantado no coração do cristianismo desde Justiniano e posteriormente exportado para os mulçumanos com o advento das cruzadas (Maalouf, 2007). O Tratado de Westfália, que daria limites fronteiriços à imposição e à perseguição religiosas, não cessava com o problema do absoluto da religião ${ }^{1}$; somente trazia para o Estado (e ao príncipe) a prerrogativa de definir a religião verdadeira e a responsabilidade de imposição religiosa. Foi neste momento que nasceram, viveram e escreveram os filósofos políticos John Locke e Baruch Espinoza. Ambos sofreram na própria pele os males da interferência negativa da religião na política por meio do extremismo religioso. Essa realidade influenciou diretamente na produção intelectual desses autores - que agregaram, entre outros temas, a preocupação sobre o problema da relação religião-política e a indicação normativa de sua solução.

Como "absoluto" entende-se o que historicamente tornou-se característico dos principais sistemas religiosos tradicionais (religiões abrâmicas ou religiões do livro): a noção de que possuem o conhecimento das verdades absolutas (divinas), do único caminho certo e revelado em direção ao Poder Supremo do Universo, enquanto que as outras religiões não possuem este conhecimento. Ou seja, é a conjugação das noções de eleição e exclusão - as quais, juntamente ao apelo pela violência são a base para o extremismo religioso. 
Partindo de pontos semelhantes, os dois filósofos políticos chegaram a conclusões sensivelmente diferentes para a questão. Enquanto que Locke sugeriu o que aqui chamamos de solução da tolerância (liberdade restrita), Espinoza encontrou como resposta a alternativa da liberdade (liberdade ampliada). A primeira, baseada no princípio da indiferença se refere a uma solução apaziguadora e sensata, porém transitória e incompleta - como a própria historia pode mostrar. Para Locke era necessário retirar o absoluto da política - ou seja, acabar com a guerra e a perseguição religiosas - por meio da separação entre política e religião e da instituição da tolerância entre igrejas, indivíduos e Estados. Por seu turno, a segunda solução, ao propor uma mudança substancial na percepção e na estrutura das religiões, pareceu ser - excluídos seus aspectos mais polêmicos - uma saída mais sustentável, porém mais árdua. Para Espinoza importava extrair o absoluto da própria religião. Isto porque percebia que uma simples separação de esferas não impediria a religião de influenciar a política e que o pedido de tolerância não seria suficiente para abolir com o extremismo de religiões que carregam o absoluto dentro de si. O ensaio propõe uma comparação entre as duas formulações, objetivando resgatar discussões relevantes acerca do debate religião-política para nossos dilemas contemporâneos.

\section{John Locke e a opção pela tolerância}

John Locke nasceu no ano de 1639, nas vésperas da Guerra Civil Inglesa (1642-49) e sentiu na própria pele os problemas da intolerância religiosa que ainda assolavam a Inglaterra. Com a condenação de Carlos I à morte em 1649, a sangrenta guerra civil acabava; instituindo-se um governo republicano que - intermediado pela ditadura de Cromwell - durou até a Restauração de Carlos II Stuart (1660). Locke começou a participar dos meios políticos neste último período, ligando-se ao Conde de Shaftesbury. Este era um dos principais chefes da ala whig, que se indispôs com o rei e foi exilado na Holanda, levando Locke consigo (CHEVALIER, 1976). No exílio (1685-1689), Locke viu a perseguição religiosa agravar-se em sua terra natal com a ascensão do católico Tiago II. Sentindo as ameaças ao seu calvinismo, escreveu as Cartas Sobre a Tolerância (1685-1686). Logo depois retornou à Inglaterra com a Revolução Gloriosa (1688) do holandês e protestante, Guilherme de Orange.

No auge de sua produção intelectual, Locke percebia os prenúncios (i) do retorno do deposto Rei James II Stuart (católico) ao poder, trazendo 
consigo a guerra e a opressão e (ii) da perseguição religiosa pela Igreja Anglicana. Essas ameaças não eram, contudo, muito mais graves do que a própria realidade já presente diante de seus olhos ${ }^{2}$. Locke resume-a de maneira metafórica: "as agitações que se produzem não derivam de um ânimo peculiar ou daquela igreja, mas da disposição comum a toda a humanidade, quando está a grunhir sob um grande peso, de tentar naturalmente se livrar do jugo que pesa sobre seu pescoço" (LOCKE, 2007, p. 88). O teórico percebia as consequências de o poder político e civil ser favorável a ideias religiosas particulares e querer aplicá-las como lei, na forma de perseguições, massacres, em suma a intolerância em ação.

A partir dessa realidade, propunha a incorporação da tolerância nos sistemas religiosos, visto que percebia a sua ausência como a causa dos males de sua época. ${ }^{3}$ Mais importante para a sua visão, afirmava ele que é preciso que se "retire do direito comum a parcialidade que lhes é imposta, que se mudem as leis, que sejam abolidas as punições às quais eles estão sujeitos, e tudo se tornará imediatamente seguro e pacífico” (LOCKE, 2007, p. 89). Argumentava, portanto, em duas vias:

Sendo assim, não é permitido que uma religião, qualquer religião, bem entendido, persiga os que não fazem parte dela, que tente convertê-los à força, mas também deve ser completamente retirado das mãos do magistrado civil qualquer responsabilidade sobre as igrejas e suas ideias (BRITO, 2007, p. 12).

Destarte, a resposta de John Locke para a pergunta "como solucionar o problema do absoluto na religião (verdades e dogmas absolutos) e a sua interferência na política?" esteve baseada na tentativa de (i) mudar o procedimento da religião em relação aos que não fazem parte dela (incorporar a tolerância) e (ii) separar as esferas política e religiosa.

O conceito de tolerância em Locke está ligado à noção de indiferença. É "sempre uma aceitação: tolera-se um mal menor com vistas a um bem maior" (BRITO, 2007, p. 13). A tolerância para com algo significa que uma suposta modificação ou alteração deste objeto representará nada de realmente importante, pois trata-se de um princípio instituído na própria indiferença

2 Já refletia Locke: "Sei que sedições são frequentemente levantadas usando a religião como pretexto, mas isso é tão verdadeiro quanto o fato de que, por causa da religião, os súditos são muitas vezes maltratados, vivendo de forma miserável” (LOCKE, 2007, p. 87).

3 É possível perceber tal afirmação na seguinte passagem: "Não é a diversidade de opiniões, algo que não pode ser evitado, mas a recusa da tolerância com os que são de opinião diferente, o que deveria ser reconhecido, que tem produzido todas as batalhas e guerras que ocorrem no mundo cristão, sob o pretexto da religião”. (LOCKE, 2007, p. 92) 
(BRITO, 2007). Esta indiferença admite a falibilidade e os erros humanos ${ }^{4}$; mas isso não exclui necessariamente a divisão entre aqueles que detêm a verdade divina e os que não a possuem. Pelo contrário, deve-se ser tolerante com a ignorância alheia acerca da verdade revelada (existente somente na própria religião de quem deve ser tolerante). A tolerância é também a marca da verdadeira igreja, cujo ofício é o de regular a vida dos homens de acordo com as regras da virtude e da piedade. Uma das consequências diretas do conceito é que a divisão entre seitas não deve ser vista como obstáculo à salvação das almas, mas sim uma virtude. ${ }^{5}$

No que diz respeito às soluções apresentadas por Locke (tolerância entre as diferentes religiões e separação das esferas política e religiosa) para o problema de sua época, é possível dividir as duas soluções principais em quatro procedimentos secundários, são eles: (i) a tolerância de igrejas e pessoas com relação à escolha religiosa de indivíduos terceiros; (ii) a tolerância entre igrejas; (iii) a tolerância do Estado frente a diferentes igrejas e seus adeptos; e (iv) o distanciamento da igreja em relação à política.

Com relação ao primeiro procedimento, o autor parte do princípio de que uma religião é uma comunidade natural e não política. Portanto, suas regras não devem interferir nos direitos e deveres políticos dos indivíduos. ${ }^{6} \mathrm{Se}$ "uma igreja é uma sociedade voluntária de homens que se juntam por acordo próprio, de modo a adorar Deus publicamente de uma maneira que eles julguem aceitável por Ele e efetiva em relação à salvação das almas" (LOCKE, 2007, p. 42); então ninguém está ligado por natureza a alguma igreja ou seita. ${ }^{7}$ Ademais, "nenhum membro de uma sociedade religiosa pode estar ligado por qualquer outro laço além daquele que procede da expectativa da vida eterna. Uma igreja, portanto, é uma sociedade de membros voluntariamente ligados para este fim" (LOCKE, 2007, pp. 42-43). E principalmente, “que

\footnotetext{
4 Uma característica da adoção desse conceito é valorizar a posição religiosa protestante do rompimento de mediações entre o crente e o seu Criador, claramente a do individualismo. A pessoa é a própria responsável por sua danação ou salvação (BRITO, 2007).

5 Locke sustentava que a "tolerância com aqueles que diferem em assunto de religião é tão agradável ao evangelho de Jesus Cristo e à razão genuína da humanidade que parece monstruoso que certos homens sejam cegos a ponto de não perceber numa luz tão clara, a necessidade e vantagem dela.” (LOCKE, 2007, p. 37)

6 "Ser membro de uma comunidade religiosa não é muito mais do ser membro de um clube qualquer" (BRITO, 2007, p. 11).

Cada indivíduo "entra voluntariamente naquela sociedade em que acredita ter achado uma profissão de fé e um culto que seja verdadeiramente aceitável para Deus" (LOCKE, 2007, p. 42).
} 
a igreja de Cristo deve perseguir os outros e forçá-los por espada e fogo a abraçar sua fé, isso até agora não foi encontrado em nenhum dos livros do Novo Testamento" (LOCKE, 2007, p. 45).

Desse modo, apesar de que "nenhuma igreja é obrigada pelo dever da tolerância a manter em seu seio qualquer pessoa que, depois de continuadas admoestações, ofenda obstinadamente as leis da sociedade" (LOCKE, 2007, pp. 46-47), o autor lembra que em ocasião alguma deve ser usada a força. A força de convencimento devem ser as exortações, as admoestações e os conselhos. A única punição que deveria ser permitida nas igrejas é a cessação de relações com o membro, deixando este de fazer parte da igreja. Ademais, homens da igreja devem não somente abster-se da violência e de todos os modos de perseguição; devem ainda ensinar a paz e a boa vontade aos homens e minimizar a aversão da mente contra dissidentes ou infiéis sustentando uma doutrina de tolerância. Esta proposição está baseada no fato de que a imposição religiosa é naturalmente negativa, há a necessidade de o indivíduo acreditar em sua própria religião. ${ }^{8}$

No que tange à tolerância de indivíduos para com indivíduos, Locke sustenta que "nenhuma pessoa privada tem o direito de prejudicar outra pessoa nos seus benefícios civis [...] [, sendo que] nenhuma injúria lhe pode ser cometida, seja ele cristão ou pagão" (LOCKE, 2007, p. 48). Assim, como propõe a indiferença, "não o punirá nas coisas desta vida, por supôlo miserável naquilo que virá depois" (Ibidem). Destarte, "ninguém, nem um indivíduo, nem igrejas, não!, nem mesmo comunidade têm algum título apropriado para invadir os direitos civis e os bens terrenos dos outros, sob a desculpa da religião" (LOCKE, 2007, p. 51) ${ }^{9}$. Há de se tolerar os homens e suas crenças $^{10}$, respeitando liberdades e julgamentos pessoais ${ }^{11}$.

8 “[...] muitas coisas são duvidosas em religião, mas pelo menos isto afinal é certo: nenhuma religião que eu acredite não ser verdadeira pode ser verdadeira ou lucrativa para mim" (LOCKE, 2007, p. 62).

9 "Qualquer um pode se valer de tantas exortações e argumentos quanto queira, tendo em vista a salvação de outro homem. Mas toda força e obrigatoriedade devem ser evitadas. Nada deve ser feito imperiosamente." (LOCKE, 2007, p. 78).

10 Para Locke "[...] um homem não viola os direitos de outro por meio de suas opiniões erradas e sua forma indevida de adoração, nem traz sua perdição qualquer prejuízo para os assuntos dos outros, já que a preocupação com a salvação de cada um pertence apenas a si mesmo" (LOCKE, 2007, p. 78).

11 Neste caso, Locke sustentava que “[...] todo homem tem autoridade suprema e absoluta de julgar por si mesmo, sendo que a ninguém mais essa questão concerne, nem pode outra pessoa receber um prejuízo devido a sua conduta" (LOCKE, 2007, p. 78). 
Cabe assim a cada homem a preocupação com a sua própria salvação, cuja obtenção não pode ser facilitada pelo esforço de outro homem, nem sua perda se transforma em prejuízo deste, isso além de não poder ser forçado a ele por uma violência externa. (LOCKE, 2007, p. 79)

O segundo procedimento da tolerância (tolerância entre igrejas) admite, com base nos ensinamentos bíblicos, que "onde quer que dois ou três se reúnam em Seu nome, Ele estará no meio deles" (MATEUS, 18:20). Ao supor duas igrejas, uma reformista e outra ortodoxa, Locke propõe que "mesmo que se pudesse dizer qual dessas duas igrejas está no caminho correto, isso não concederia à igreja ortodoxa nenhum direito de destruir a outra" (LOCKE, 2007, p. 50). Percebe-se que ainda sobrevive a noção de que uma igreja pode estar correta enquanto que a outra pode não estar. A tolerância, ou indiferença, seria para Locke a forma de conciliar a relação entre justos e iníquos. Todavia, há algumas exceções para a necessidade de tolerância, quais sejam: (i) a não aceitação do ateu dentro da sociedade civil; (ii) os intolerantes serão intolerados; e (iii) não haverá tolerância para com igrejas cujos preceitos que entram em conflito com as leis civis e o bem público ${ }^{12}$. Portanto,

se a lei da tolerância fosse uma vez instituída, de modo que todas as igrejas fossem obrigadas a pôr a tolerância como fundamento de sua própria liberdade, e a ensinar que a liberdade de consciência é direito natural de todo homem, pertencendo tanto aos dissidentes quanto a elas mesmas, e que ninguém pode ser obrigado em assuntos de religião, que pela lei, quer pela força" (LOCKE, 2007, p. 85)

O terceiro procedimento da tolerância (Estado tolerar diferentes igrejas e seus adeptos), parte do princípio que o Estado deve possuir uma jurisdição neutra e que o magistrado deve ser o responsável pela execução das leis. A jurisdição do magistrado deve abranger somente assuntos civis. Todo o poder civil, o direito e o domínio são limitados pela tarefa única de promover funções que não podem nem devem ser estendidas para a salvação das almas. Isto deve ocorrer pelos seguintes pressupostos: (i) "O cuidado das almas não está sob responsabilidade do magistrado civil, assim como de nenhum outro homem" (LOCKE, 2007, p. 39); (ii) o poder do magistrado

12 “[...] nenhuma opinião contrária à sociedade humana ou àquelas regras morais necessárias à preservação da sociedade civil devem ser toleradas pelo magistrado” (LOCKE, 2007, p. 82). 
consiste em força externa, sendo que somente "a verdadeira e salvadora religião consiste a persuasão interna da mente, sem o que nada poderia ser satisfatório para Deus" (LOCKE, 2007, p. 40) ${ }^{13}$; e (iii) “mesmo que o rigor das leis e a força das punições fossem capazes de convencer e mudar a mente dos homens, ainda assim isso não ajudaria em nada a salvação das suas almas" (LOCKE, 2007, p. 41). Em suma, "todo o poder do governo civil relaciona-se apenas com os interesses civis dos homens e está limitado aos cuidados com as coisas deste mundo e não tem nada a ver com mundo que virá depois" (LOCKE, 2007, p. 42). ${ }^{14}$

No que concerne à relação do Estado para com os súditos, Locke argumenta: "O cuidado para com a alma de um homem pertence a si mesmo, e deve ser deixado a ele" (LOCKE, 2007, p. 55). Isto porque "nem o próprio Deus pode salvar os homens contra as vontades destes" (LOCKE, 2007 , p. 56). O autor valoriza, portanto, o livre-arbítrio individual ${ }^{15}$. A religião está dentro do próprio homem ${ }^{16}$, a partir de liberdades mantidas após o contrato social ${ }^{17}$. Referente ao posicionamento do Estado frente às sociedades religiosas, o magistrado deve tolerá-las não fazendo diferenças

13 "Apenas a luz e a evidência podem provocar uma mudança nas opiniões dos homens, e essa luz não pode de maneira nenhuma vir de sofrimentos corporais ou de qualquer outro pena externa" (LOCKE, 2007, p. 41).

14 Percebe-se o conteúdo anti-anglicano dessa passagem. "Ao afirmar que o magistrado civil não deve, nem pode, se imiscuir em assuntos de religião, Locke se levantava contra seu próprio soberano, já que os monarcas ingleses são, desde Henrique VIII, os “defensores da fé" da Igreja Anglicana, quer dizer a Igreja da Inglaterra” (BRITO, 2007, p. 19)

15 "O único e estreito caminho que leva ao Céu não é melhor conhecido pelo magistrado do que pelas pessoas privadas e, portanto, não posso tomá-lo como meu guia, pois que provavelmente é tão ignorante do caminho quanto eu mesmo e certamente está menos interessado do que eu na minha salvação" (LOCKE, 2007,p. 59).

16 " $[\ldots]$ apesar de a opinião do magistrado ser segura, e o caminho que ele aponta verdadeiramente evangélico, ainda assim, se eu não estiver completamente persuadido em minha própria mente, não terei segurança para segui-lo. [...] Posso enriquecer por uma arte que não me dá prazer, posso ser curado de uma doença por remédios nos quais não levo fé, mas não posso ser salvo por uma religião da qual desconfio e por um culto que desprezo. [...] Somente a fé a sinceridade íntima levam à aceitação junto a Deus" (LOCKE, 2007, p. 61).

17 “[...] os bens temporais e a prosperidade exterior da sociedade, que são as únicas razões pelas quais os homens entram em sociedade, e tudo o que procuram e almejam nela. E fica também evidente que a liberdade em relação à eterna salvação permanece com os homens, e que cada um deve fazer o que em sua consciência está persuadido ser aceitável ao Todo Poderoso, de cuja satisfação e aceitação depende a felicidade eterna, pois a obediência é devida em primeiro lugar a Deus, e depois às leis” (LOCKE, 2007, p. 80) 
entre a dita igreja nacional e outras congregações - seja no âmbito do culto exterior ${ }^{18}$ como no dos artigos da fé19. Locke sustenta ainda que "nem o direito nem a arte de governar carregam necessariamente consigo um conhecimento correto de outras coisas, menos ainda da religião verdadeira" (LOCKE, 2007, p. 58).

[...] Se a reunião em assembléias solenes e a observância de dias de festa e cultos públicos forem permitidas para qualquer tipo de crente, todas essas coisas devem ser permitidas, com a mesma liberdade, para presbiterianos, independentes, anabatistas, arminianos, quacres e outros. Mais ainda, se pudermos falar com franqueza, como é adequado a um homem que fala a outro, nem pagão, nem maometano, nem judeu, devem ser excluídos dos direitos civis de sua comunidade por causa de sua religião. (LOCKE, 2007, p. 91)

O quarto e último procedimento da tolerância (distanciamento da igreja com relação à política) propõe, em relação ao clero, que "onde quer que sua autoridade se origine, desde que seja eclesiástica, ela deve estar contida dentro dos limites da igreja, não podendo de maneira alguma ser estendida aos assuntos civis, porque a igreja, em si mesma é uma coisa completamente separada e distinta da comunidade" (LOCKE, 2007, p. 52). Suas decisões "não podem ser mais bem embasadas ou seguras que as dele [do rei], nem podem todos os seus votos em concordância adicionar qualquer força nova ao poder civil" (LOCKE, 2007, p. 61). Também os pecados não devem ser punidos pela lei, somente quando a injúria cometida se dá contra as leis da comunidade.

As mudanças propostas pelo teórico no concernente à separação das esferas política e religiosa têm raízes em sua percepção sobre o contrato social. Para ele, o contrato social (pacto político) é feito para formar um governo entre pessoas com o intuito de alcançar melhores condições do que as do estado de

18 “[...] o magistrado não tem poder para forçar, pelo poder da lei, seja na sua própria igreja, ou ainda menos em outra, o uso de quaisquer ritos ou cerimônias na adoração de Deus" (LOCKE, 2007, p. 63). "[...] também não tem qualquer poder para proibir a adoção das mesmas, de modo como já foram recebidas, aprovadas e praticadas por uma igreja." (LOCKE, 2007, p. 68).

19 " $[\ldots]$ as opiniões especulativas e os artigos da fé (como são chamados), que precisam ser acreditados não podem ser impostos a qualquer igreja pela lei do país pois seria absurdo que coisas que não dependem do poder dos homens para ser realizadas pudessem ser permitidas por leis" (LOCKE, 2007, p. 75). "Além disso, o magistrado não deve proibir a pregação ou profissão de nenhuma opinião especulativa em qualquer igreja, porque estas absolutamente não têm relação com os direitos civis dos súditos” (LOCKE, 2007, p. 76). 
natureza. Ou seja, dar proteção diante de ameaças externas e da propriedade. $^{20}$ Nesse âmbito, a separação total entre os poderes político e religioso é um dos cuidados para que haja segurança após o contrato (BRITO, 2007). Após o contrato, nem as igrejas devem sair dos seus limites, nem os que estão do lado de fora devem, de alguma forma se imiscuir nas peculiaridades da igreja (BRITO, 2007, p. 13). A tirania, a intolerância na comunidade é causada pelo infeliz acordo entre igreja e Estado, entre religião e política. ${ }^{21}$ Locke propõe então a separação entre os assuntos da religião e os do governo civil. ${ }^{22}$

Em essência, a abordagem de Locke é pioneira e valiosa no que concerne às proposições para a solução da influência negativa da religião na política (absoluto) - por este motivo foi adota pela maioria dos Estados modernos ocidentais. De fato, sugestões prudentes são evidentes em sua análise; como as propostas (i) de que um indivíduo não deve ser forçado a uma religião nem a religião deve interferir nos direitos civis do indivíduo, (ii) de que não se deve utilizar da religião como desculpa para invadir os direitos individuais, (iii) de que o Estado não deve impor uma religião ao indivíduo nem fazer diferenciações entre igrejas, e (iv) de que o poder do clero não pode ser estendido a outros assuntos civis. Como visto, essas propostas foram parte de sua teorização mais ampla que apontava a necessidade de se retirar o absoluto da política por meio da separação entre esferas do sagrado e profano e da instauração da tolerância como prática civil.

Todavia, essa dupla solução indicada por Locke possui lacunas ontológicas. Em primeiro lugar, a proposição não previa garantias para que a tolerância ocorresse; não havia mecanismos que constrangessem indivíduos, igrejas ou Estados a tolerar (serem indiferentes) outras práticas religiosas. ${ }^{23}$ Em segundo lugar, Locke não pressupôs que a própria tolerância

20 Nota-se, entretanto, que o estado natural de Locke é diferente daquele de Hobbes. Tratase de lugar em que a convivência não é de todo prejudicial. O contrato viria apenas para tornar o convívio melhor e mais seguro (CHEVALLIER, 1976)

21 "Se cada um deles tivesse se restringido aos seus próprios limites, um atendendo ao bemestar mundano da comunidade, a outra zelosa da salvação das almas, teria sido impossível que qualquer discórdia jamais tivesse ocorrido entre eles” (LOCKE, 2007, p. 94).

22 "Se isso não for feito, não terão fim controvérsias que sempre surgem entre aqueles que têm, a pretensão de ter, por um lado, interesse pela alma dos homens e, por outro, cuidado pela comunidade" (LOCKE, 2007, p. 39)

23 Uma decorrência desse problema é que hoje, "mesmo com uma constituição garantindo a liberdade de práticas religiosas, mesmo com uma separação entre igreja e Estado já aceita nos inícios do século XX até pelo Vaticano, nem por isso a intolerância religiosa deixa de se mostrar aqui e ali, provando que não morreu. E há o caso da intolerância do Estado em relação às religiões" (BRITO, 2007, p. 25). 
- mesmo se em algum momento fosse de fato adotada por todos - é por si só insuficiente. Isto ocorre pelo fato de ela não lidar com os mecanismos profundos nos quais é sustentada a maior parte dos sistemas religiosos: a percepção de que a sua própria religião é a portadora da verdade absoluta - o que aqui definimos como o absoluto na religião. É plausível argumentar que enquanto essa percepção religiosa estiver latente não se firmarão raízes do respeito para com outras práticas religiosas e a própria tolerância será insuficiente. Não se conceberá um princípio de verdade em uma crença alheia; serão sempre os escolhidos frente aos iníquos. Em terceiro lugar, ao mesmo tempo em que Locke não pretendeu lidar com o problema da verdade absoluta na religião, não tratou abertamente sobre a questão da perseguição religiosa dentro da própria igreja. Ou seja, a violência contra discípulos que possuem interpretações diversas àquelas impostas pelos dogmas internos. Finalmente, em quarto lugar, não percebeu que (i) nem todos os Estados adotariam uma separação clara entre religião e política (laicização), mantendo acesa a influencia do absoluto da religião na política; e (ii) que é utópica e ingênua a própria confiança de que, instituindo-se a laicidade do Estado, estariam definitivamente separadas religião e política. A religião possui outros mecanismos tão efetivos para influenciar política quanto aqueles mais institucionalmente visíveis, da união entre igreja e Estado.

Portanto, Locke acaba por proteger as religiões de sua responsabilidade em influenciar negativamente a política e, desse modo, não propõe repensálas e reformá-las. ${ }^{24} \mathrm{~A}$ ausência de uma proposta de reforma religiosa está diretamente relacionada à preferência pelo conceito de tolerância (baseado na indiferença), pois quaisquer mudanças nas percepções e estruturas religiosas são, de acordo com o autor, indiferentes (insignificantes) para o Estado e para o problema religião-política como um todo. É de forma oposta a essa noção que se situa a linha de argumento de Baruch Espinoza.

\section{Baruch Espinoza e a opção pela liberdade}

A solução de Baruch Espinoza para a pergunta "como solucionar o problema do absoluto na religião e a interferência na política?” é sensivelmente diferente daquela proposta por John Locke. O ibérico-holandês

24 "Perseguições por motivos religiosos, as guerras, torturas e execuções, muitas vezes na fogueira, eram afinal acontecimentos comuns em sua época. A responsabilidade dessas atrocidades todas Locke não punha nas costas do cristianismo, mas sim na intervenção indevida de crenças religiosas no mundo político” (BRITO, 2007, p. 12) 
sugere a necessidade de (i) uma mudança nas bases da própria religião, o que aqui se define como a solução da liberdade (como se verá a seguir); e (ii) a separação de esferas, não necessariamente da religião e da política, mas da religião (ação e obediência) e da filosofia (razão).

Espinoza viveu entre 1632 e 1677 , tendo 16 anos no momento do Tratado de Westfália. O evento mais importante da sua trajetória foi o êxodo de sua família judaica da Península Ibérica, devido às perseguições religiosas, em direção à Holanda, onde Espinoza nasceu e viveu toda a sua vida. A república da Holanda presenciava o seu "século de ouro", mas não estava livre de conflagrações marítimas (principalmente na Guerra Anglo-Inglesa) e conflitos políticos internos (entre os partidos orangista, republicano, calvinista ortodoxo e calvinista liberal). Percebe-se que, assim como John Locke, Espinoza viveu em uma época de agitações: foi contemporâneo das turbulências que o extremismo religioso causava na política. Entretanto, um fato ocorrido em sua vida foi fundamental para a concepção de sua obra: a excomunhão da sinagoga em 1656, pelo fato de ser um judeu liberal. Este acontecimento foi o que diferiu particularmente a sua vida com relação a de Locke e fundamentou centralmente o seu intento de ir além, de retirar a percepção do absoluto de dentro da própria religião. O fato ocorreu antes da produção do Tratado Teológico-Político (1670), obra que sofreu grande influência desse episódio.

A solução da liberdade de Espinoza é baseada na tentativa de inserir este princípio dentro do conceito de religião. Dessa forma, o autor trabalha com a Escritura (Antigo e Novo Testamento) para demonstrar a diferença entre dogmas de obediência e dogmas de verdade, e, por conseguinte, entre religião e filosofia. Espinoza inicia seu argumento sustentando que a Escritura deixa a religião em absoluta liberdade e não tem nada em comum com a filosofia. A Escritura contém o Verbo de Deus revelado aos profetas, a saber: o conceito simples de "obedecer inteiramente a Deus praticando a justiça e a caridade" (SPINOZA, 2008, p. 12). Esse conceito se resume na máxima do amor Universal, de amar ao próximo como a si mesmo - o único dogma que pode ser extraído da Escritura a partir de um método racional ${ }^{25}$. Conclui Espinoza

25 No capítulo VII do Tratado Teológico-Político, Spinoza argumenta sobre qual seria o verdadeiro método para interpretar a Escritura. Conclui ele que deve ser aquele que elabora a sua história autêntica. Ou seja, tudo o que se encontra na Escritura deve ser esclarecido com base na doutrina universal da mesma escritura, exigindo nada além da luz natural (em oposição à sobrenatural ou a uma autoridade externa). Segundo o autor, esse método realista dá a cada um a "suprema autoridade de explicar a Religião e julgar em matéria religiosa, uma vez que isso pertence ao direito individual” (SPINOZA, 2008, p. 137). 
que o conhecimento revelado tem a finalidade da obediência, diferentemente do conhecimento natural, destinado à razão.

Chega-se, aqui à relevante distinção feita pelo autor entre dois conceitos, quais sejam: fé (que utiliza como sinônimo de religião e teologia) e filosofia. Como fé, tem-se o ato de "[...] atribuir a Deus características tais que, se forem ignoradas, desaparece a obediência para com Deus e se, pelo contrário, se pressupõe essa obediência, elas têm necessariamente de se supor" (SPINOZA, 2008, p. 217). A fé salva pela obediência e aquele que é obediente possui necessariamente a verdadeira fé. Ademais, somente a ação comprova a fidelidade. ${ }^{26}$ Espinoza sustenta ainda que os verdadeiros Anticristos são aqueles que perseguem os homens honestos por não acreditarem nos mesmos dogmas. Para o verdadeiro fiel o amor à justiça e à caridade, transpassado em seus atos (obediência), é o que basta.

Aqui surge naturalmente a oposição entre dogmas verdadeiros e dogmas de obediência. Para Espinoza, “a fé não exige expressamente dogmas verdadeiros, exige sim, dogmas que são necessários para a obediência, isto é, que confirmem a vontade no amor do próximo, pois só em função desse amor cada um estará em Deus e Deus estará em cada um" (SPINOZA, 2008, p. 218). Assim, o autor tenta retirar a noção de verdades absolutas da religião (que aqui chama de dogmas verdadeiros) afirmando, no caso do cristianismo, que só pertencem à fé dogmas de obediência a Deus que fortalecem os deveres amplos de amor e justiça. Propõe, destarte, o autor: “[...] não haverá na Igreja lugar para mais controvérsias. Nem há que ter receio, a partir de agora, de enumerar os dogmas da fé universal [verdadeiros]" (SPINOZA, 2008, p. 219). Estes, tendo a forma que adquirirem, devem convergir para a percepção de que "existe um ser supremo que ama a justiça e caridade, ao qual, para ser salvos, todos têm de obedecer e adorar, cultivando a justiça e a caridade para com os próximos" (Ibidem). Nota-se que para seguir este dogma da obediência é indiferente saber o que é Deus (o seu conceito) e quais são os seus atributos. ${ }^{27}$

26 “[...] ninguém deve ser considerado fiel a não ser pelas suas obras. Se as obras forem boas, quem as pratica é fiel, mesmo que discorde dos outros fiéis no que respeita aos dogmas; se, pelo contrário, as obras forem más, ele é infiel, por mais que as suas palavras concordem com a dos fiéis" (SPINOZA, 2008, p. 217).

27 A não ser as percepções decorrentes do próprio dogma de obediência, a saber: (i) que existe um Deus supremo; (ii) que existe um único Deus; (iii) que ele está em toda a parte (nada lhe é oculto para que possa julgar a justiça e a caridade); (iv) Deus tem o domínio e o direito sobre todas as coisas; (v) que o culto e a obediência consiste na justiça e na caridade; (vi) que só aqueles que obedecem a Deus obtêm salvação; (vii) que Deus perdoa os pecados dos que se arrependem. 


\section{Espinoza sugere que}

[...] cada pessoa deve adaptar esses dogmas de fé [obediência] à sua capacidade de compreensão e interpretá-los como lhe parecer que é mais fácil aceitá-los sem reticências e de ânimo plenamente convicto, a fim de obedecer a Deus com total aquisciência [,] [...] [pois] ninguém é fiel a não ser em função de sua obediência. (SPINOZA, 2008, p. 221)

Chega-se, portanto, à diferenciação entre fé e filosofia. Aqui Espinoza pretende separar ambas as esferas e mostrar a liberdade que a filosofia concede aos indivíduos. Para Espinoza, entre fé (ou teologia, ou religião) e filosofia não há nem relação nem afinidade obrigatória. Se o objeto da fé é a obediência e a piedade, o da filosofia é a verdade. Se os fundamentos da fé são as narrativas históricas e os textos, os da filosofia são as noções comuns. A fé deve conceder a máxima liberdade para cada um filosofar - ou seja, pensar o que quiser sobre todas as coisas (âmbito propriamente da razão). A fé possui o domínio da piedade e da obediência, enquanto que a filosofia (razão) possui o domínio da verdade e do saber.

O autor salienta que quem quiser adaptar as Escrituras à razão (filosofia) "terá de atribuir aos profetas muitas coisas que eles nem por sonho pensaram e de interpretar incorretamente o seu pensamento" (SPINOZA, 2008, p. 223). Assim tudo o que for além da obediência da justiça e caridade na Escritura não é concernente à teologia ou à palavra de Deus, estando os homens livres a pensar o que quiserem acerca disso sem constituir crime. Dessa forma "nem a Escritura deve se adaptar à razão, nem a razão deve se adaptar à Escritura" (SPINOZA, 2008, p. 229). ${ }^{28}$ Portanto, é necessário "deixar a cada um a liberdade de julgar e a possibilidade de interpretar os fundamentos da fé [verdade] segundo a sua maneira de ser, e não ajuizar da fé de ninguém a não ser pelas suas ações conforme forem piedosas ou ímpias. Só assim poderão todos obedecer a Deus de livre e inteira vontade e dar valor apenas à justiça e à caridade" (SPINOZA, 2008, pp.12-13).

Sobre os limites desta liberdade de cada um pensar e dizer o que pensa, Espinoza busca explicações baseadas no direito natural. Para o autor este direito determina-se pelo desejo e pela potência (ao invés da razão) -

28 Todavia, cumpre salientar que a teologia é a própria revelação, o objetivo da escritura. Ademais, "se analisarmos os seus preceitos e os ensinamentos que dá para a vida, verificaremos que ela está inteiramente de acordo com a razão” (SPINOZA, 2008, p. 229). Isto na medida em que seu intuito e finalidade não contradizem a razão e são universais. 
apesar de admitir uma razão motora na natureza. O filósofo acredita que a característica do estado natural é a insegurança, onde há direitos iguais para homens guiados pela razão e para os guiados pela cólera. O contrato social vem a partir de uma busca por segurança e o direito natural passa a ser determinado não pelo desejo dos indivíduos, mas pelo poder e pela vontade de todos em conjunto (SPINOZA, 2008, p. 237). O indivíduo transfere para a sociedade a sua própria potência, sendo que esta sociedade passa a deter a soberania suprema (o poder supremo) cujas ordens deve-se seguir. O indivíduo renuncia aqui a liberdade de agir conforme entende, apesar de garantir a liberdade de pensar dizer o que pensa. ${ }^{29}$

Nesse sentido, "ninguém pode ser absolutamente privado do seu direito natural e que os súditos mantêm, quase como um direito da natureza, alguns privilégios que não lhes podem ser recusados sem graves perigos para $\mathrm{O}$ Estado" (SPINOZA, 2008, p. 13). A "liberdade pode e deve ser concedida, sem que isso lese a paz social e o direito das autoridades soberanas, e que, pelo contrário, não pode ser suprimida sem graves riscos para a paz e em detrimento de todo o Estado" (SPINOZA, 2008, p. 13). ${ }^{30}$ Assim, as leis em matéria de opinião são naturalmente provocadoras à sociedade e ameaçam a manutenção do próprio Estado.

Se se quiser, pois que se aprecie a fidelidade e não a bajulação, se se quiser que as autoridades mantenham intacto o poder e não sejam obrigadas a fazer cedência aos revoltosos, terá obrigatoriamente de conceder a liberdade de opinião e governar os homens de modo que, professando embora publicamente opiniões diversas e até contrárias, vivam apesar disso em concórdia. (SPINOZA, 2008, p. 308)

Enfim, as únicas opiniões subversivas são "aquelas cuja aceitação implica na imediata cessação do pacto pelo qual o indivíduo renunciou o direito de agir conforme entendesse" (SPINOZA, 2008, p. 304).

29 A partir desse momento a função do Estado é dar segurança para o indivíduo existir e agir, ou seja, garantir a sua liberdade. O soberano (ou as autoridades soberanas) é o detentor do poder que os homens têm de seguir se não quiserem ser inimigos do Estado ou agir contra a razão. Este poder não está sujeito a nada (nem ao direito divino) e a ele todos devem obediência. O súdito é aquele que age em direção ao bem comum, por ordem da autoridade suprema, sendo útil também a si mesmo (SPINOZA, 2008).

30 "[...] um Estado para ser bom deve conceder aos indivíduos a mesma liberdade de filosofar que a fé, tal como vimos, lhe concede" (SPINOZA, 2008, p. 305). 
Em relação à separação de esferas, percebe-se que Espinoza não advoga necessariamente a cisão entre religião e política, mas sim entre religião e filosofia. Como visto, a primeira seria a esfera da ação e da obediência enquanto que a segunda cumpriria o papel da razão e da liberdade de formulação e expressão humanas. Salienta-se que este último ponto é visivelmente baseado em sua percepção sobre a relatividade do conhecimento humano, composto por verdades relativas e contingentes - em oposição à Verdade Absoluta própria apenas a Deus (SPINOZA, 2003).

Por fim, importa salientar que Espinoza percebe o problema da interferência negativa da religião na política. A partir do estudo acerca do Estado hebreu de Moisés e de seus grupos sucessores, Espinoza constata: (i) "quão pernicioso, quer para a Religião, quer para o Estado, é conceder aos ministros do culto o direito de decretarem o que quer que seja ou se imiscuírem em assuntos políticos" (SPINOZA, 2008, p. 282); (ii) "quão perigoso é remeter questões de ordem puramente especulativa para o direito divino e basear as leis em opiniões sobre as quais os homens costumam ou, pelo menos, podem discutir" (SPINOZA, 2008, p. 283) 311 (iii) “quão necessário, tanto para o Estado como para a religião, é reconhecer aos poderes soberanos o direito de decidir o que é lícito e o que é ilícito” (SPINOZA, 2008, p. 283). Esta última conclusão liga-se à percepção do autor de que "[...] os que detêm o poder soberano são os responsáveis e os intérpretes, não só do direito civil, mas também do direito canônico, e [...] só eles possuem o direito de discernir o que é justo e o que é injusto [...]." (SPINOZA, 2008, pp. 13-14).

Portanto, para Espinoza, a religião ainda pode influenciar a política, mormente as leis, desde que a partir da noção de que a primeira diz respeito apenas a dogmas de obediência, de justiça e caridade; o que aboliria, ou quase isso, a possibilidade de extremismos. Assim,

a religião só adquire força de lei por decreto daqueles que detêm a soberania, que Deus não exerce nenhum reinado especial sobre os homens a não ser através daqueles que detêm o poder soberano, e que, além disso, o culto religioso e as práticas piedosas se devem conciliar com a paz e o interesse público, razão pela qual só as autoridades soberanas o devem definir e ser seus intérpretes (SPINOZA, 2008, p. 287).

31 Desse modo, sustenta novamente Spinoza, "não há nada mais seguro que se possa descobrir para qualquer Estado do que considerar como piedade e culto religiosos unicamente as obras, isto é, a prática da justiça e da caridade, deixando a cada um a liberdade de ajuizar sobre todo o resto [...]” (SPINOZA, 2008, p. 283). 
Por conseguinte, para que haja um Reino de Deus sobre os homens há a necessidade da mediação realizada pelo soberano. Há aqui uma percepção oposta à laicização (separação entre igreja e Estado) argumentada por Locke. Ressalta-se, porém que Espinoza parte de uma noção completamente diferente sobre o conceito de religião e sobre o que consiste seus dogmas.

[...] não há nada melhor para a segurança do Estado que fazer consistir a piedade e a religião unicamente na prática da caridade e da justiça e limitar o direito das autoridades soberanas, tanto em matéria sagrada como profana, aos atos, deixando a cada um a liberdade de pensar aquilo que quiser e de dizer aquilo que pensa. (SPINOZA, 2008, p. 310)

Em suma, Espinoza percebeu a insuficiência de se retirar o absoluto da política apenas pelo rompimento dos laços desta com a religião. Entendeu que enquanto existisse o absoluto na religião, a política não estaria livre de extremismos. Foi, portanto, buscar a raiz do problema, ou seja, a existência de dogmas de verdade como motores da fé. A forma de retirar o absoluto da religião foi a instrumental, Espinoza passou a chamar de religião coisas muito simples e pouco passíveis de diferenças interpretativas, a saber: a obediência aos princípios da obediência e da ação em direção à caridade e à justiça. O que concerne à interpretação sobre Deus, a Unidade, o Bem, o Mal, a Gênese, a vida, a morte, a história de Jesus, o comportamento dos crentes e todos os demais elementos que historicamente foram a base de conflitos intra e inter-religiosos no ocidente e fora dele, Espinoza passa a chamar de filosofia. Esta esfera, estando fora das fronteiras da religião, seria o ambiente ideal para as interpretações livres e pessoais - o que não significaria pecado, nem muito menos um distanciamento da verdade divina.

Como visto, a proposição de Espinoza é, na prática, uma instrumentalização política para o seu conceito metafísico exposto em Ética demonstrada à maneira dos Geômetras, o qual sugere que, fora a Verdade conhecida por Deus (Absoluta), todas as demais verdades (as dos humanos) são relativas e contingentes. Por isso, nenhuma religião pode pretender conhecer a Verdade divina, muito menos pretender impô-la a outros, desrespeitar as verdades de outras religiões ou mesmo impedir que seus próprios adeptos interpretem de forma particularmente diferente questões conceituais sobre Deus. 


\section{Considerações finais}

Historicamente, a primeira solução, de John Locke, foi a vencedora. Trata-se da alternativa posta em prática de forma ampla com a laicização dos Estados modernos a partir do século das luzes (XVIII). Todavia, mesmo após a instituição do Estado laico a religião não parou de influenciar a política. Percebe-se hoje, por exemplo, um mundo caracterizado por extremismos religiosos (terrorismo islâmico, teoconservadorismo norte-americanos, etc.), pela existência de Estados não-laicos e pela uma crescente importância da religião nas relações internacionais (HUNTINGTON, 1993, 1996; FOX; SANDLER, 2004; JUERGENSMEYER, 1993).

Este processo é explicado, dentre outras maneiras, pelo fato de que a religião e a religiosidade interferem na política justamente ao influenciarem indivíduos e grupos no processo de tomada de decisão política. Mais especificamente, (i) afetando a construção das funções utilitárias próprias à escolha racional, (ii) como elemento parte da decisão em ambientes de racionalidade limitada e (iii) influenciando a produção de instituições informais e formais que constrangem a tomada de decisão política. Percebese, pois, que, apesar de sensata em seu contexto e imprescindível em muitas de suas proposições normativas, a solução de Locke foi insuficiente na resolução do problema da influência negativa (extremismos, guerras, etc.) da religião na política.

A provocação manifesta por Espinoza, por seu turno, atesta uma agenda sagrada e secular, mais árdua, porém mais realista. Importa aqui o esforço teológico e social para a reforma de religiões em direção a uma cultura de tolerância e respeito a direitos fundamentais. No primeiro caso, são relevantes debates internos e esforços de construção de religiões menos dogmáticas, e reformas tais quais as experimentadas contemporaneamente pela Igreja Católica. No segundo caso, cabe à sociedade civil ampliar o conhecimento e a discussão sobre tais alternativas filosóficas e teológicas e denunciar o absolutismo religioso, fortalecendo e empoderando correntes inclusivas que invariavelmente trarão reflexos mais igualitários e inclusivos no ambiente político.

Se a religião não cessa de levar a noção de verdades absolutas e excludentes e o próprio extremismo para a política, então cabe alterarmos a estrutura das religiões. Deve-se então limitar os dogmas religiosos aos dogmas de obediência, deixando que a liberdade individual escolha os dogmas de fé (dogmas verdadeiros). Trata-se de dividir de forma mais reta a filosofia da 


\section{Igor Castellano da Silva \\ Gabriela Schneider}

religião; mas, mais do que isso, de possibilitar a aproximação de ambas e de proporcionar ao indivíduo a liberdade de ter percepções particulares acerca de Deus. O absoluto da religião - ou seja, aquela percepção escorada em dogmas de fé que assume "a minha é a verdadeira religião de Deus" - é, assim, suprimido. Cumpre concluir que esse é um processo já em realização, a partir da complexificação do fenômeno da secularização (BURITY, 2001; BERGER, 1999; HURD, 2007). Como apontado por Inglehart e Norris (2004), esta nova realidade sinaliza a perda de espaço de religiões tradicionais e a ascensão de religiões não-dogmáticas; o que abre novos caminhos para a relação entre religião e política.

\section{Referências}

ASAD, Talal. Formations of the Secular: Christianity, Islam, Modernity. Stanford: Stanford University Press, 2003.

BERGER, Peter L. The Desecularization of the World: a Global Overview. In: Berger, Peter L. (ed.). The Desecularization of the World. Resurgent Religion and World Politics. Washington/Grand Rapids, Ethics and Public Policy Center/Eerdmans, 1999.

BRITO, Ari Tank. Introdução. In: LOCKE, John (2007). Carta sobre a Tolerância. São Paulo: Hedra, 2007.

BURITY, Joanildo A. Religião e Política na Fronteira: desinstitucionalização e deslocamento numa relação historicamente polêmica. Revista de Estudos da Religião, n. 4, p. 27-45, 2001. BURITY, Joanildo A. Religião, política e cultura. Tempo Social, revista de sociologia da USP, v. 20, n. 2, p. 83-113, 2008.

CASTELLANO DA SILVA, Igor; PERES, Lorenzo de Aguiar. Religiosidade e decisão política: Problemas nas áreas de Política Externa e Gestão da Guerra. Revista Cadernos de Estudos Sociais e Políticos, v. 2, n. 3 (Jan/Jul), p. 34-94, 2013.

CHEVALLIER, Jean-Jacques. As grandes obras políticas de Maquiavel a nossos dias. 3. ed. Rio de Janeiro: Agir, 1976.

DARK, K. R. (ED.). Religion and International Relations. Basingstoke: Palgrave Macmillan, 2000 .

DAVIE, Grace. A Secular Age beyond the West: Religion, Law and the State in Asia, the Middle East and North Africa. Social Forces, v. 98, n. 1, p. 1-3, 2019.

FOX, Jonathan. Religious Armed Conflict and Discrimination in the Middle East and North Africa: An Introduction. Civil Wars, v. 15, n. 4, p. 407-410, 2013.

FOX, Jonathan; SANDLER, Shmuel. Bringing Religion Into International Relations. Series Culture and Religion in International Relations. New York: Palgrave Macmilan, 2004.

HATZOPOULOS, Pavlos; PETITO, Fabio (EDS.). Religion in International Relations:

The Return from Exile. Basingstoke: Palgrave Macmillan UK, 2004. 
HUNTINGTON, Samuel P. The Clash of Civilizations and the Remaking of World Order. New York: Simon \& Schuster, 1996.

HUNTINGTON, Samuel P. The clash of civilizations? Foreign Affairs, v. 72, n. 3 (Summer), p. 22-49, 1993.

HUNTINGTON, Samuel P. Who Are We? The Challenges to America's National Identity. New York: Simon \& Schuster, 2004.

HURD, Elizabeth Shakman. The Politics of Secularism in International Relations. Princeton: Princeton University Press, 2007.

INGLEHART, Ronald; NORRIS, Pippa. Sacred and Secular: Religion and Politics Worldwide. Cambridge: Cambridge University Press, 2004.

JAWAD, Haifaa A. Pan-Islamism and Pan-Arabism: Solution or Obstacle to Political Reconstruction in the Middle East. In: JAWAD, Haifaa A. (Ed.). The Middle East in the New World Order. Boulder: Palgrave Macmillan, 1997. p. 140-159.

JUERGENSMEYER, Mark. The New Cold War?. Berkeley: University of California, 1993.

LOCKE, John. Carta sobre a Tolerância. São Paulo: Hedra, 2007.

MAALOUF, Amin. As cruzadas vistas pelos árabes. São Paulo: Brasiliense, 2007.

MACHADO, Maria das Dores Campos. Política e religião: a participação dos evangélicos nas eleições. Rio de Janeiro: Editora da FGV, 2006.

MILLER, Paul D. Evangelicals, Israel and US Foreign Policy. Survival, v. 56, n. 1, p. 7-26, 2014 ORO, Ari Pedro. A laicidade no Brasil e no Ocidente. Algumas considerações. Civitas - Revista de Ciências Sociais, v. 11, n. 2, p. 221-237, 2011.

RENGGER, N. On theology and international relations: World politics beyond the empty sky. International Relations, v. 27, n. 2, p. 141-157, 2013.

SHAH, Timothy Samuel; PHILPOTT, Daniel. The Fall and Rise of Religion in International Relations: History and Theory. In: SNYDER, Jack (Ed.). Religion and international relations theory. New York: Columbia University Press, 2011. p. 26-52.

SNYDER, Jack (ED.). Religion and international relations theory. New York: Columbia University Press, 2011.

SPINOZA, Baruch de. Correspondencia. Madrid: Alianza Editorial, 1988.

SPINOZA, Baruch de. Ética demonstrada à maneira dos Geômetras. Tradução Jean Melville. São Paulo: Martin Claret, 2003.

SPINOZA, Baruch de. Tratado Teológico-Político. Tradução Diogo Pires Aurélio. São Paulo: Martins Fontes, 2008.

TAYLOR, Charles. A Secular Age. Cambridge, MA: Harvard University Press, 2007.

WARNER, Carolyn M.; WALKER, Stephen G. Thinking about the Role of Religion in Foreign Policy: A Framework for Analysis. Foreign Policy Analysis, v. 7, n. 1, p. 113-135, 2011.

Submetido em: 24-1-2020

Aceito em: 14-8-2020 